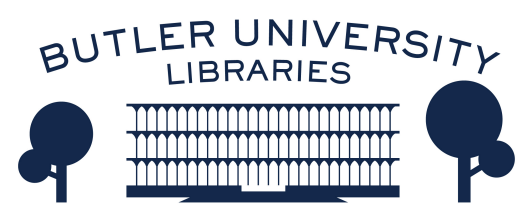

Journal of Hindu-Christian Studies

Volume 26

Article 14

November 2013

\title{
Book Review: The Saint in the Banyan Tree: Christianity and Caste Society in India
}

Chad M. Bauman

Butler University, cbauman@butler.edu

Follow this and additional works at: https://digitalcommons.butler.edu/jhcs

Part of the Religion Commons

\section{Recommended Citation}

Bauman, Chad M. (2013) "Book Review: The Saint in the Banyan Tree: Christianity and Caste Society in India," Journal of Hindu-Christian Studies: Vol. 26, Article 14.

Available at: https://doi.org/10.7825/2164-6279.1553

The Journal of Hindu-Christian Studies is a publication of the Society for Hindu-Christian Studies. The digital version is made available by Digital Commons @ Butler University. For questions about the Journal or the Society, please contact cbauman@butler.edu. For more information about Digital Commons @ Butler University, please contact digitalscholarship@butler.edu. 


\section{BOOKS REVIEWS}

\section{The Saint in the Banyan Tree: Christianity and Caste Society in India. David Mosse. Berkeley: UC Press, 2012, xix + 385 pages.}

THE Saint in the Banyan Tree focuses on the Jesuit mission in Ramnad (southeastern Tamil Nadu), which began in the $17^{\text {th }}$ century, and in particular on the village of Alapuram (a pseudonym) and its popular pilgrimage site devoted to Santiyākappar, or Saint James the Greater. Mosse, Professor of Social Anthropology at SOAS (University of London), conducted research for the book over three decades, beginning in the early eighties. The book combines ethnographic reflection with historical chapters on the Jesuit mission, and Mosse himself describes the work as an "historical project with anthropological objectives" (ix). Readers conversant with Mosse's earlier and exceptional work on this topic will encounter familiar material; five of the six chapters draw upon previously published work.

The Saint in the Banyan Tree focuses on the relationship of Christianity and Tamil culture, but does not present these as stable entities or reified concepts. Rather, Mosse demonstrates how the very categories of "religion" and "culture" were sites of contestation and development, "produced in historically and locally specific ways" (xi) over several centuries of interaction. One of the most important particularities of this interaction of course had to do with the early and influential Jesuit missionary, Roberto de Nobili, who drew upon Thomist dualism to insist upon the separability of Christian faith (e.g., truth, salvation, morality, etc.) from Tamil custom, language, and social organization. Culture was the neutral vessel into which true Christian faith could be implanted, so long as it was free from, or after it had been stripped of its "idolatrous" elements. Jesuit missionary religion thereby produced "the secular," according to Mosse, "even before the colonial secular produced the modern category of 'religion' as we understand it today" (xi-xii).

Notably, the early Jesuits considered caste a neutral custom, among the adiaphora, or "indifferent things." Combined with the idea that Christian truth stood beyond and above the social, the effect was to relativize caste society. Catholicism "placed significant limits on the naturalization of inequality" (271) and thereby made it possible for Tamils to reflect critically on caste hierarchies and their place within them. But this did not immediately produce social disjuncture among convert communities. Rather, as Mosse repeatedly emphasizes, Jesuits consigned caste to the order of adiaphora precisely in order that it might be tolerated among the converts. Early Jesuit missionaries displayed no particular desire to eradicate caste prejudice or caste privilege. Nobili, after all, combined the argument that caste was a neutral social 
practice with his own strategic adoption of the marks and signs of brahmanical custom.

As Susan Bayly does so well in Saints, Goddesses, and Kings (Cambridge University Press, 1989), Mosse shows how Catholic religion interacted intimately with local religious traditions and practices. In this interaction, "A recognizable Tamil symbolic logic ordered a complex...array of divine beings and relationships across religious boundaries so as, importantly, to allow [the converts] continued relationships with neighboring people and their gods, isolating social relations from the implications of the antipagan absolutism of the [early] missionaries" (270). Likewise, the Jesuit missionaries were constantly drawn into local social and political dynamics, becoming alternative sources of power and prestige, and offering up significant titles and honors (mariyātai) as part of their church functions and festivals. "The key to mission success in the Tamil countryside," Mosse writes, "lay in the way in which Catholic churches became the target of political-economic investments, along with temples and other pilgrim centers, and especially as the object of royal patronage within a particular indigenous mode of statecraft" (268). It was only after many centuries of development that the Catholic relativization of caste contributed to anything like the radical social critique of caste that emerged from Jesuit circles after the 1980s.

In fact, one of the most important contributions of The Saint in the Banyan Tree is its argument, presented persuasively and in great detail, that the critique of caste for which Catholics, and Jesuits in particular are now well known did not originate from the ethereal realm of Christian social ethics, standing apart from and looking critically at Tamil/Indian culture, but was rather provoked by the sense, among Catholics, of an inconsistency between Catholic Christianity's "claimed universal ethics and its caste particularism" (276), and especially by the outrage expressed by dalit Jesuit priests at their experience of caste prejudice and oppression within the Catholic church. "A forceful dalit social movement arose...from the experience of dalitness rather than of Christianity" (277), Mosses contends, and the movement "indicated the failure of Nobilian distinctions" because in it, caste had become "idolatry" (277). What began as an internal critique and dialogue, then, only later expanded, intersecting with, influencing, and being influenced by broader Indian efforts to address caste prejudice within the international discourse of "human rights". If for Nobili, Moss writes, "caste was a vehicle for the intercultural transmission of Christian faith, today Christianity is a vehicle for the internationalization of dalit human rights" (278).

The Saint in the Banyan Tree is also an extended conversation about cultural continuity and discontinuity in the interaction of Jesuit missionaries with Tamil cultures and peoples. Debates about the relative extent of syncretism/hybridity versus cultural "rupture" (to use the term popularized by Joel Robbins) in Christian history have become revitalized in recent years, in part through the growing and increasingly sophisticated anthropological literature on Christianity around the world (typified by the work of Robbins, Fenella Cannell, Webb Keane, and others). Mosse argues with, and often against this literature, implicitly denying the possibility of universal conclusions on the matter, and repeatedly demonstrating the importance of attention to 
specific historical and cultural contexts. In fact, throughout the book, Mosse is impressively sensitive to local particularities, pointing out how the historical and political processes he describes advance differently in the $17^{\text {th }}$ and $20^{\text {th }}$ centuries, or in Alapuram and other villages, or in Tamil Nadu and Kerala, or in Catholic and Protestant contexts.

This sensitivity points to what is perhaps the greatest strength of the book, and that is its productive juxtaposition of historical and ethnographic research. Readers in search of more strictly historical resources may prefer the broadly South Indian-focused work of
Susan Bayly, or Ines Županov's research on the early Jesuit missions. And Mosse himself has authored a number of more purely ethnographic studies. But Mosse's combination of thick description with longue durée historical coverage, his equal facility with anthropology and the archive, with-among others-Pierre Bourdieu and Marshall Sahlins, is what makes The Saint in the Banyan Tree a unique, and uniquely successful book, and one with provocative theoretical implications.

Chad M. Bauman

Butler University

\section{Dalit Theology and Christian Anarchism. Keith Hebden, Farnham, Surrey, England: Ashgate Publishing, 2011, 171 pages.}

THE fruit of Keith Hebden's doctoral studies at the University of Birmingham, as well as his field work in Karnataka and Gujurat, Dalit Theology and Christian Anarchism, attempts to address what Peniel Rajkumar has labelled the "polemic binarism" endemic to Dalit and many other forms of liberation theology (2). That is, liberation theologies tend to set one class of persons against another-in this case, Dalits against mainstream Hindus-in an attempt to reform or revolt against the dominant regime. Such theologies, Hebden contends, miss the central issue: namely, the intrinsic violence and systemic oppression of the modern nation-state against all classes of persons subject to it. Hence, the need to reformulate Dalit theology from within a more consistently anarchist framework, which seeks out "alternative forms of voluntary organization" (8) as a way of subverting national identities and liberal governments.

The argument proceeds in three major movements. In the first three chapters, Hebden establishes a context for his study, drawing on Leo Tolstoy, Walter Wink and Jacques Ellul to define Christian anarchy (ch. 1), rereading modern Indian history in terms of the "Missionary God" of the British colonial project and the "Vedic God" of Hindu nationalism (ch. 2), and diagnosing the failure of the Indian church to address questions of caste oppression and violence - particularly in the context of the 2002 violence in Gujarat (ch. 3). The key problem, he suggests, is the homogenization of both Christian and Indian identities according to a false logic of universalization. The next two chapters turn first to such early $20^{\text {th }}$ century Christian 